Howe, C. (2013). Epistemic Engineering and the Lucha for Sexual Rights in Postrevolutionary Nicaragua. The Journal of Latin American and Caribbean Anthropology, 18(2), 165-186. http://doi.org/10.1111/jlca.12015

\title{
Epistemic Engineering and the Lucha for Sexual Rights in Postrevolutionary Nicaragua
}

\author{
Cymene Howe \\ Rice University
}

\begin{abstract}
Resumen
Desde 1992-2007, Nicaragua tuvo la problemática distinción de mantener la ley de sodomía más represiva de todas las Américas. En base al trabajo de campo realizado durante varios años con activistas por lo que ellos llaman 'la lucha' por los derechos sexuales, este artículo se enfoca en la 'máquina epistemológica' de la lucha por los derechos sexuales en Nicaragua. En el texto se analizan los dos pilares que han enmarcado dicho activismo: 'Orgullo Lésbico-Gay' y 'Una Sexualidad Libre de Prejuicios', cada cual con su propio origen ideológico y propósitos epistemológicos. Como representantes de discursos políticos y estratégicos de cambios sociales, los activistas han llevado a cabo actuaciones políticas y han divulgado públicamente los discursos para elaborar artesanalmente la forma en que la lucha 'sale' hacia el exterior, se da a conocer y es entendida por el conjunto del cuerpo político nicaragüense. A través de este proceso, los activistas han desarrollado estructuras epistemológicas sobre derechos sexuales en discursos múltiples, incluyendo los de 'liberación universal,' 'derechos minoritarios' y una ética comunitaria, así como el Sandinismo.
\end{abstract}

\begin{abstract}
From 1992 to 2007, Nicaragua had the dubious distinction of maintaining the most repressive antisodomy law in the Americas. Based upon several years of field research with activists involved in what they have called the lucha for sexual rights, this article considers the "epistemological engineering" of Nicaragua's sexual rights struggle. It discusses two distinct frameworks that have informed the work of advocacy: "Orgullo Lésbico-gay" (Lesbian and Gay Pride) and "Una Sexualidad Libre de Prejuicios" (Sexuality Free from Prejudice) — both of which have different ideological [End Page 165] origins and epistemological purposes. As managers of political logics and strategists of social struggle, activists have utilized political performances and publicly disseminated discourses in order to craft the way in which the struggle will "come out," and ultimately how sexual rights will be understood by the larger Nicaraguan body politic. Through this process, activists have developed the epistemic dimensions of sexual rights in multiple registers, including those of universal liberation and minority rights, as well as earlier iterations of a communitarian ethos, including Sandinismo.
\end{abstract}


When you are dressed to the nines and ready for a night on the town, Nicaraguans are apt to say, "andas bien armada," (you are going out "well-armed"). Those attending the fiesta for La jornada por una sexualidad libre de prejuicios (Gathering for A Sexuality Free From Prejudice) were definitely bien armadas. Sponsored by several nongovernmental organizations (NGOs) and smaller advocacy groups in Nicaragua in late June every year, the fiesta concludes a weeklong series of events to promote better understanding of sexual diversity and rights. As the party got underway at a local restaurant, plates of bocas (snacks) were passed around, made from deepfried cheese and salty slices of green plantain. When guests arrived they were greeted by friends with kisses on the cheek, and Flor de Caña, Nicaragua's popular national rum, began to flow as toasts were made. By the time we were ready to begin, the audience numbered close to 100, and as the disco ball overhead was geared up and the stage lights beamed, cheers and whistles filled the darkening room. Squinting in the spotlight, with microphone in hand, our host shouted out a boisterous greeting: "Welcome! Welcome to you all! We are all so glad to be here because this is our party, for us, for the solidarity of lesbians and homosexuals in Nicaragua!"

The host of the Sexuality Free from Prejudice (SFFP) party rallied much heartfelt enthusiasm for the ideal of solidarity. The fiesta was, he announced, a space and a time to celebrate "us." However, creating solidarity and establishing a unified agenda for sexual rights in Nicaragua has not been easy to accomplish. From the point of view of activists committed to the "lucha," or struggle, for sexual rights, achieving a sense of solidarity and crafting a coherent message and discursive framing for their cause has involved many types of negotiation.

Advocates have had to mediate differences among and between themselves, and they have had to confront the Nicaraguan state, which, in 1992, instituted the most repressive antisodomy legislation in the Americas.

As this discussion unfolds, it will become clear that sexual rights advocates draw both inspiration and tactical knowledge from their personal experiences as well as from Nicaragua's national political history. It will also be clear that activists [End Page 166] utilize the now nearubiquitous discourse of human rights (Boellstorff 2003; Butler 2004; Žižek 2005) and rhetorical strategies that emphasize "autological" subjectivity (Povinelli 2007). ${ }^{1}$ A liberal logic of rights and movements has been persuasive in Nicaragua's postrevolutionary, neoliberal economic climate, and has, in part, set the stage for cultural and political reconfigurations of sexuality. However, I will argue that activists have not been bound by these logics. Instead, they have translated aspects of the country's revolutionary ethos into terms commensurate with contemporary sexual rights' politics, often reconfiguring translocal political practices so that they resonate more profoundly with local political histories and priorities. Scholarship on social movements and the role of NGOs in neoliberal Latin American contexts has demonstrated how multiculturalist discourses and claims to democratic citizenship and rights offer both opportunities and pitfalls as activists attempt to re-orient the political potential of marginalized populations (Hale 2002; Postero 2006). With similar concerns, anthropologists (and others) have been interested in better understanding the dissemination and application of liberal rights frameworks in part because they originate in the global North, and thus are colored by their imperial roots (Goodale and Merry 2007). However, here I will contend that sexual rights activists are in fact keenly aware of these "origin stories" and their implications. Consequently, activists' use of these political approaches - including autological sexual citizenship, multiculturalist belonging, and universalist human rights - is more strategic than naively subscriptive. 
This article is based on extended field research with sexual rights advocates in Nicaragua from 1999 until 2006 (see Howe 2013). During my time in Managua and other cities in the country's western region, I worked directly with several NGOs and small organizations that were committed to sexual rights advocacy. I conducted dozens of interviews with individuals in the overlapping communities of feminists and sexual rights advocates, as well as others in and outside of the gay and lesbian scene. Attending events such as those described in this article (including press conferences, festivals, film screenings, and meetings), as well as participating in lesbian discussion groups and mass media productions dedicated to social justice, has provided me with a broad perspective on sexual rights advocacy in Nicaragua. Activists, I have found, are persuasive and astute meditators who are concerned about the values of their struggle and how these may affect the possibilities for sexual rights. Based on my conversations with activists and others in Nicaragua, I have come to the conclusion that beyond their commitments to social change, sexual rights advocates ought to be understood as a class of experts (Mitchell 2002). By crafting certain kinds of discourses and developing particular strategies, advocates are engaged in an artisanal mode of advocacy to reshape the ways in which sexuality will come to be understood, and lived, in Nicaragua. [End Page 167]

\section{Engineering Epistemologies and Performing Politics}

For a time, Nicaragua earned international recognition as a country that succeeded in overthrowing four decades of dictatorial rule by the Somoza dynasty. The Sandinista Revolution (1979) was one of few successful social revolutions in Latin America, and the forces that animated it envisioned a communitarian project that would bring together strands of Marxism, liberation theology, and a strong sense of national patrimony (Field 1999). During the Sandinista era, Nicaraguan women's political participation increased dramatically. While the state developed formal political projects intended to incorporate women, the priority was to ensure women's continued involvement in the revolutionary endeavor rather than generate new approaches to gender politics or commit to a truly feminist project (Molyneux 1985; GonzálezRivera 2011). However, as they sought to remedy the particular forms of discrimination that women faced-including legal barriers and structural inequalities, as well as those seen to be "cultural," such as abuses of machismo - many Nicaraguans gained skills that would prove invaluable in their work with international allies, NGOs, and development agencies in the decades to come. Feminism, women's politicization, and the debates around gender politics were critical to the development of lesbian and gay politics in Nicaragua (Babb 2001, 2003; Randall 1994).While Sandinista Nicaragua did not institute provisions to persecute sexual minorities as in some other revolutionary contexts, neither did the state embrace the cause of sexual rights (Randall 1993, 1994; Thayer 1997). When a number of Nicaraguans and internacionalistas (foreigners in solidarity with the revolutionary project) began meeting in the mid-1980s to discuss the particular forms of discrimination they believed they faced as sexual minorities, their meetings were infiltrated by Sandinista state security and halted in the name of protecting the revolutionary state.

The Sandinista project provided practical experience for a generation of sexual rights activists. But it also, and perhaps more importantly, furnished a political model that combined diverse ideological forms, blending them into a relatively unified vision for social transformation. Even as contemporary activists engage with politically liberal notions of sexual 
subjectivity and human rights, they draw from a national political history based upon communitarian ideals and a hybrid approach to social justice. While the Sandinista's engagement with sexual rights was not ideal, the end of the revolutionary regime ushered in a tide of conservative social policies as well as further neoliberal economic reforms (Babb 2001; Dye and Close 2004; Kampwirth 2006). With the electoral defeat of the Sandinistas in 1990, many members and loyalists of the Frente Sandinista de Liberación Nacional (FSLN) were freed from their party obligations and became dedicated to feminist and human rights projects, often through the auspices of civil society organizations and NGOs. The early 1990s was a period of rapid expansion for NGOs, many of [End Page 168] them funded by foreign allies, and a handful of them dedicated to sexual health, education, and rights. NGOs and civil society activism that centered on gender and sexual issues cannot be divorced from the fact that, legislatively and fiscally, the country was experiencing a conservative turn that compelled many sexual rights advocates to action.

Article 204 of the Nicaraguan penal code, ratified in 1992 by the Nicaraguan National Assembly, was one indicator of Nicaragua's socially conservative turn. The law mandated up to three years imprisonment for "anyone who induces, promotes, propagandizes or practices in scandalous form sexual intercourse between persons of the same-sex" (Bolt González 1996). Partly because of the unflagging commitment of sexual rights activists, and in part due to other political machinations and the return of the Sandinistas to presidential power, the Nicaraguan National Assembly voted to repeal the antisodomy legislation in 2007. ${ }^{2}$ During its tenure, Article 204 was not widely applied as a prosecutorial tool. However, its existence served as a threat to anyone, or any organization, that dared to "promote" or discuss homosexuality or lesbianism. It was a tool of intimidation and surveillance that could be drawn upon by individuals or the state. Perhaps more importantly, Article 204 had the effect of legally codifying and exacerbating discrimination against sexual minorities in a context where, in prior times, disrespect had been the norm (Adam 1993).

Nicaraguan cochones (fags), as Roger Lancaster (1992) found in the late 1980s and early 1990s, were often the object of burla (mockery) rather than street violence. During my field research, many Nicaraguans who identified as homosexual, gay or lesbiana (or who were marked by others as cochones or cochonas) concurred that the greatest bias they experienced was from families, peers, and coworkers, rather than from gay bashers or perpetrators of homophobic street violence. One explanation for this relative lack of overt hate crime is that Nicaraguan cochones have historically subscribed to "gender-" and "role"-based models of homosexuality. In this model, dishonor and stigma do not adhere to both participants in homosexual activity, but only to those marked as inappropriate in their gendered or sexual behavior (Lancaster 1992). ${ }^{3}$ In this context, "masculine" men could have insertive or activo sex with "effeminate" and putatively sexually pasivo cochones, and never be castigated for their behavior, nor designated as queer. Rather, cochones were part of a gendered system that marked them as raro and un-manly (and therefore suspect), but not criminally so. Cochonas (masculine dykes) have not figured prominently in academic formulations of these gendered/sexual systems although, as in other non-Western settings, this is slowly changing (see Bolt González 1996; Ferguson 1991; Howe 2013; Randall 1993, 2004). In the popular imagination, cochonas are marked as masculina in comparison to their femenina (or muy mujer) female partners, replicating the gender distinctions attributed to cochones and masculine/active men as well as heterosexual formulations of [End Page 169] masculinity and femininity. To generalize a sexual history that requires much more specificity (as all sexual histories do), ${ }^{4}$ Nicaragua has experienced changes in its sexual lexicon 
as well as the degree of public recognition for same-sex sexuality. It has been a place where there has been both some tolerance for sexual minorities as well as a place where virulent antigay legislation has been institutionalized.

Nicaraguan activists, many of them feminists and many of them current or former Sandinistas, rallied against the antisodomy laws in different ways. They created legal petitions at the outset, and in a more sustained way, convened homosexual and lesbian discussion groups and produced sex-positive educational radio and television programing, among other things. Activists have been, by necessity, keenly aware of the distinctions to be made among (relatively) private disclosures of sexual identity, being "out" (declarado/a), and the risks involved in mounting more public claims for sexual rights. As they maneuver the politics of sexual rights from the intersubjective spaces of discussion groups, for example, into the bright light of public scrutiny, activists have had to strategize how to "go public" with the lucha. Before political interventions can be scaled to reach a broader audience, activists have had to work through their priorities for the lucha. As sexual rights activists have endeavored to shape their distinct approaches to local and translocal political paradigms, they have been in conversation, and sometimes conflict, with the agendas of other advocates, even when they all share a commitment to greater public tolerance and the creation of new ways of imagining sexual difference. Here, I consider how sexual rights advocates have sought to create a coherent message and epistemological framing for their struggle, and how they have grappled with the politics of both presentation and representation. Or, to put it in the parlance of lesbian and gay disclosure, this will be a close examination of how the struggle for sexual rights in Nicaragua has "come out."

The first part of this article contrasts the distinct political frameworks of Orgullo Lésbico-Gay (Lesbian and Gay Pride) and Una Sexualidad Libre de Prejuicios (SFFP), suggesting that they have very distinct ideological origins and epistemological purposes. Pride focuses attention on a minority population of lesbianas, gays, and homosexuales, while the strategic imaginary of "Free from Prejudice" envisions a larger constituency for sexual rights: it implies that the entirety of the Nicaraguan nation has a sexuality and thus the right to be free from prejudice and discrimination, even if an individual does not ascribe to the identities of lesbiana, gay, or homosexual. This ethnographic account describes some of the ways in which these political positions are questioned, contested, and negotiated in activists' deliberations. Activists must engage in mediations among and between their own political priorities in order to render and refine their public presentations of sexual rights. As they debate, modify, and ultimately perform their political interventions, sexual rights advocates work to collectively define how sexual rights will come to be known and understood by the Nicaraguan public. It is precisely [End Page 170] because these politics are intended to reshape public understandings of sexuality that activists' interventions demand a carefully crafted representational strategy. Rather than simply seeking to change policy (such as overturning the antisodomy law) activists have, instead, aimed for a re-mapping of the cultural logics of the country. It is through these political performances and discourses that activists are engineering the epistemology of the lucha, charting the ways in which the struggle will come to be known and, ultimately, how samesex sexuality will be understood. 


\section{Pride and Prejudice}

In the late afternoon, the streets of Managua are often packed with taxis and recycled American school buses refashioned into commercial vehicles to transport people in and out of the capital. On a fading afternoon in late June 2001, a local AIDS/HIV prevention organization decided to take advantage of the streets' evening bustle by rallying a coterie of 20 young men to commandeer the sidewalks. Carrying banners proclaiming that "Everyone has a right to their sexuality" and chanting "Human rights are our rights," the troupe made their way down a crowded boulevard toward the Nicaraguan National Assembly and the Office of the President. Armed with yellow balloons that read "No al artículo 204," the protesters managed momentarily to fill the skies with their demands. The group then found their way to an iconic figure in Managua: the hyper-masculine statue of a revolutionary soldier that towers above one of the city's main thoroughfares in an area known historically as a popular location for men to seek out sex with other men. Erected by the Sandinistas, the statue honors Nicaragua's fallen soldiers in the Contra war. Although his official designation is "El guerrillero sin nombre" (The Unknown Warrior) he is commonly referred to as "Rambo." Despite the fact that he was meant to stand in opposition to the kind of U.S.-centered imperialism represented by the original Rambo, the statue embodies much more than one designation alone can capture. In an effort to ensure a more durable message than was possible with balloons and banners, the protestors decided to plaster the base of Rambo with sky blue stickers proclaiming, "No al artículo 204." Affixing their message here was, as they said, "simbólico" (symbolic).

This was a polyvalent act that could be interpreted as a critique of the Sandinistas' failure to fully establish lesbian and gay rights; but it was also very clearly a critique of the (then current) antisodomy law. The activists' political performance, moreover, visibly rebuked machismo and the masculine prerogative that the protesters consider to have bolstered the antisodomy legislation. Their symbolic message was, in the simplest terms, a sign of dissent. But the march, and its messages, held other significance as well. It is no coincidence, for instance, that the NGO and the young men orchestrated their manifestación in late [End Page 171] June. This temporally attuned their protest with lesbian, gay, bisexual, transgender (LGBT) Pride celebrations around the globe, which are themselves timed to coincide with the 1969 Stonewall rebellion that inaugurated the gay and lesbian liberation movement in the United States. Using the rainbow flag and discourses of human rights claims, the protest was saturated with globally recognized markers of lesbian and gay politics. While these elements appear to be signs of a Nicaraguan movement for gay and lesbian pride, this would only tell part of the story, because the balloons and banners were in this instance part of Nicaragua's annual SFFP events; and these events stand in some distinction to the politics of Pride.

The lucha for sexual rights in Nicaragua has not been a single project. Indeed, activists involved in the struggle often subscribe to very different visions of how to navigate and structure the lucha going forward. Some sexual rights proponents insist that Orgullo Lésbico-Gay is the ideal approach to sexual rights advocacy. Pride, for them, has the potential to transform how Nicaraguans understand same-sex sexuality. The appeal of Pride is that it allows for a sense of solidarity, community, and coalition with a larger, indeed global, population of gay, lesbian, and queer-identified people. Advocates of Pride see themselves as part of a larger collective project predicated on adopting a sexual identity and, thereby, codifying links to like-identified sexual minorities. 
Other Nicaraguan sexual rights advocates, however, believe that "exuality Free from Prejudice" is the more effective framework, and, indeed, the preferred method for establishing equality and embarking on a larger, national discussion about sexuality for both gay and straight Nicaraguans. Advocates of SFFP highlight the importance of situating their vision of sexual diversity within the Nicaraguan body politic. They work to frame their messages of tolerance and sexual difference in a national rubric that echoes some of the communitarian values of Sandinismo. But they also insist that in addition to tolerating the nonnormative sexuality of lesbians and gay men, Nicaraguans ought to imagine themselves as having "a sexuality" and thus all stand to benefit from sexual rights.

\section{Por Una Sexualidad Libre de Prejuicios}

La jornada por una sexualidad libre de prejuicios (Gathering for A Sexuality Free From Prejudice) was launched in the early 1990s by sexual rights activists, feminist allies, and Nicaraguan NGOs in an effort to challenge the new antisodomy law. The educational presentations and gatherings for SFFP continue to be financed by a handful of feminist, sexual rights, and HIV/AIDS-prevention NGOs, most of them based in the capital city. While NGOs are the central architects of these events, additional planning, suggestions for activities, and the volunteer labor [End Page 172] needed to make it all possible are often provided by less institutionally embedded advocates: feminists, university students, long-time homosexual rights activists, or parishioners from the transnational lesbian and gay church, La Iglesia de la Comunidad Metropolitana (the ICM).

While SFFP events were initiated to challenge the antisodomy law, since the early 1990s they have become much more. The SFFP campaign has become, and continues to be, the largest, best-known, and most well-funded demonstration of sexual rights in the country. The epicenter for SFFP is the capital city, but events have been held in other parts of the country as well. The city of Matagalpa, a longtime Sandinista hub in Nicaragua's coffee-growing region, holds SFFP events, for example. Chinandega, a city near the Honduran border with a high incidence of HIV/AIDS, and the town of San Juan del Sur, a favorite beach enclave of the Somozas, Sandinistas, and now expatriates, have also hosted these events. The Jornada has grown dramatically, in both scope and scale, since its debut. Initially there were a day or two of events, but by 1999, the activities stretched for nearly a week and featured call-in radio shows, television appearances by activists, press conferences, research presentations, magazine canvassing, and film screenings. Each of these public presentations demanded a careful crafting of both content and form.

During the 2001 SFFP events, the film Antes que Anochezca (Before Night Falls) (2000, dir. Julian Schnabel) — based on the life of Reinaldo Arenas, a gay Cuban writer-was screened for an audience of 50 or so at an old Sandinista haunt in Managua, the Coro de Ángeles (Chorus of Angels). Following the film, a Cuban intellectual discussed the persecution of Cuban homosexuals and the relative tolerance found in Sandinista Nicaragua. In addition to presenting films and hosting educational discussions, local NGOs also showcased research reports on HIV transmission in Nicaraguan cities and rates of depression and suicide among young gay men. The magazine Fuera del Closet (Out of the Closet), ${ }^{5}$ published by the HIV prevention and sexual rights organization Fundación Xochiquetzal, was distributed around the city. A homosexual man and a lesbian woman also made appearances on an early morning TV talk show 
to relay their experiences of discrimination in the job market and the social stigma surrounding homosexuality in Nicaragua. Radio shows, such as "Human Rights for homosexuals and lesbians: Your perfect match may be with someone of the same sex" and "True Love Knows No Prejudice" were broadcast on youth radio programs. In order to create maximum attendance and public visibility, SFFP events have been advertised in the national newspapers, on leaflets and posters, and through the broadcast media.

To frame the political priorities of SFFP and to encourage participation in the events, the feminist NGO, Puntos de Encuentro, circulated the following announcement by e-mail and had copies printed up and distributed: [End Page 173]

The Jornada por una sexualidad libre de prejuicios has become a space where sexuality is demystified in order to speak about sexuality as a natural entity, with the end result of learning, understanding and creating, overall, respect for the human species, all of whom are diverse and equal. The Jornada has always promoted the need to have a sexual scientific education. This helps us to recognize that there is sexual diversity and that its existence is an undeniable right.

The Jornada's mission, as the notice indicates, is to highlight sexual diversity and equality as broad social concerns.

Notably, the announcement does not refer to gay and lesbian rights specifically, nor does it mention homosexuality, male or female. While in part this can be read as a concession to the antisodomy law, it also speaks to a larger set of claims. Establishing sexuality that is "free from prejudice" is, in this narrative, not simply of concern only to sexual minorities: rather, it is equated with a "respect for the human species." This particular positioning of sexual rights, and the intrinsic values of rights and equity that are embedded within it, demands a respect for sexual diversity that is broadly based and society wide. As they draw attention to processes of learning about, understanding, and demystifying sexuality, advocates aim to craft an epistemological framework that proposes to change the way that Nicaraguans understand and think about sexuality.

Advancing the possibility of a "sexual scientific education" based upon the proposal that sexuality is a "natural entity," the proponents of SFFP also gesture toward notions of progress, modernity, and the (putative) objectivity of science. These naturalizing discourses situate sexuality as an innate quality that exists in everyone. Sexuality is thus presented as both natural and amenable to social intervention; it is a biopolitical location where education and a process of demystification can take place. The political logic of SFFP is, on the one hand, a subtle approach, treading carefully before the law; but it is also meant to promote broad transformation and general social tolerance, rather than emphasizing minority politics. For SFFP activists, the larger Nicaraguan population is the constituency that must be convinced of the value and applicability of sexual rights. It is this greater collective that must be solicited and schooled in sexuality in order to become the proper subject of sexual rights. Put another way, the goal of SFFP is to promulgate the notion that all Nicaraguans have a sexuality, and, in turn, a right to it.

Advocates of SFFP have been attentive to the ways in which sexuality and rights become combined and presented to the Nicaraguan public. For example, Lilia, a lead organizer for SFFP for several years, outlined ways in which some events should be presented at an upcoming press conference. She wanted to ensure that each member of our organizing committee was well versed on how to speak with journalists who would, in turn, be communicating with the Nicaraguan [End Page 174] public through their newspaper, radio, and television coverage. During one of our meetings, Lilia explained, 
When you talk to the press, when you approach them, you don't tell them the event is for homosexuals and lesbians. No. You approach it suavemente (gently/mildly). Don't scare them right away. Ease into it. This is a sexuality free from prejudice [here she drew out the phrase].

Don't start by telling them about the cochones and cochonas!

Emphasizing the phrase "sexuality free from prejudice" and gesturing with a wink and a nod (while appropriating the derogatory terms cochón and cochona as only a true insider can), Lilia discouraged her comrades from highlighting "the fags and the dykes" in their conversations with reporters. She wanted to be sure that SFFP was articulated in a very particular way. Her recommendation was appreciated by committee members and everyone nodded in agreement. Lilia, a publicly out lesbian, did not mean to deny to the press that SFFP advocates are committed to promoting sexual rights, nor that they are disinterested in remediating prejudice against homosexuales, lesbianas, and other sexual minorities. However, she did want to underscore that the framework for sexual rights needed to be presented to the public in carefully calibrated ways, that is, gently; in other words, her goal of fostering greater public tolerance for sexual rights called for a more seductive subtlety around the issue of "the fags and dykes."

At the SFFP press conference a few days later I was curious to see if Lilia's message would be received in the way that she intended. The press conference was well attended by most of Nicaragua's prominent media sources, with journalists gathered in a large room at a local NGO. Following a presentation about upcoming SFFP events, I spoke with two male journalists (one from a national daily and the other from a local television station) and asked for their thoughts about the upcoming activities. One replied,

The way I understand it is that one shouldn't have anything against other people, like homosexuals or lesbians. Because this is the kind of sex that is most criticized. And so we need to value people not for their sexuality, but for who they are.

His colleague added,

I would say the same thing: that we can't be prejudiced against people just because they maintain relations with people of the same sex ... And we need to recognize that there are people who have relations with people of the same sex. This is something that we need to understand.

Although they were supposed to leave the meeting with an understanding that SFFP was "not all about the cochones and cochonas," the journalists seemed convinced, nonetheless, that the events were oriented toward the concerns of [End Page 175] sexual minorities. One journalist used polite and nonderogatory terms (lesbianas and homosexuales as opposed to cochones and cochonas) and the other named the practice (maintaining relations with people of the same sex) rather than the person. However, despite Lilia's attempt to downplay same-sex sexuality, this approach seemed to prove more difficult in practice than in theory.

The journalists' default assumption was that SFFP was, essentially, for lesbianas and homosexuals - marked categories within the rubric of sexuality. SFFP aspires to create a broadly based campaign to promote sexual tolerance and encourage a way of understanding sexuality as something that is embodied by, and of interest to, all Nicaraguans. Defining this national constituency may meet with uneven results, but these attempts to broaden the purview of sexual rights beyond minority politics suggests an affinity with earlier communitarian impulses found in Sandinismo. It is a political imaginary that privileges a national ethical and epistemological transformation rather than an emphasis on a particular marginalized population. For activists 
such as Lilia, recognizing and, in turn, managing the conjunction of "local" political frameworks (such as Sandinismo) and those of globally circulated discourses of human rights is central to sexual rights advocacy. In addition to echoing Sandinismo, SFFP subscribes to a democratizing, human rights-based narrative that locates sexuality and sexual subjectivity in everyone, everywhere.

\section{Revolutionary Sexology}

When I arrived at a large lecture hall at the Universidad Centroamericana (or LaUCA), the wellrespected Jesuit University in Managua, it was a standing-room only event. More than 300 students were present and the mood was boisterous. Two renowned Nicaraguan sexologists were present to discuss the influences of nature and nurture in the development of homosexuality, and to debate the issue of childrearing by lesbians and gay men. Before the speakers began, I asked several students what they thought of the day's topic. One young woman shared the following:

Well, I believe that it is very important and I think that young people need to eliminate these myths and dogmas that force us to close ourselves off. It is an idea that encloses us and so we need to have more choices in order to develop ourselves.

What do you mean by “dogma," I asked. She responded,

Dogma is like a recipe, there is no way out, it is boxed in. And you can't get away from it. It's like the same as prejudice. That's what dogma is. We have to get out of it. And to develop ourselves and to see sexuality as something that is very natural. It is part of human development.

[End Page 176]

Another student explained that for him, "It seems like an opportunity to choose whichever sex, a man or a woman, that each person likes without prejudice. Without any social impediment." His friend added, "I agree. Because nowadays nobody can reprimand the choice of others. This is something of the past."

The students agreed with many of the values animating SFFP events: overcoming prejudice and viewing sexuality in terms of human development and science. More importantly perhaps, they averred that choice (or whatever "each person likes") was an important value. This suggests a contemporary worldview that relegates antihomosexual bias to the past. Liberal values of choice and tolerance are interwoven in the students' narratives, and they phrase their thoughts in terms of temporal movement and progress: to be free from prejudice is to be more personally "developed." Their narratives, not unlike the principles of SFFP, follow a modernist logic and underscore the belief that it is the responsibility of individuals to adhere to a more tolerant sensibility.

Promoting progress and overcoming antiquated dogma was also a central element in the lecturers' presentations. During the question and answer period following the talks, one of the speakers, a clinical psychologist specializing in sexuality, called attention to a student's question about the effect of the revolutionary period on sexuality and marriage.

Someone just asked a question that is very important, because probably many of you were either very young, or just born in the 1980s. She asked if the 1980s marked changes in people's lives, and if we think about the word "revolution" it is a revuelta (an uprising or a mixing up) of 
everything. This was a social revolution, where the social structure and political structure were radically changed, but obviously there were a number of changes. There were a lot of people who got divorced. And a lot of people who couldn't stand these changes. But those who were really committed kept their relationships and those who weren't, lost them. But it wasn't the revolution that did this: people getting divorced or that people became lesbians.

What the revolution did was open a space. And the people who had been living hidden lives because of the censorship, with this new space, now able to be less isolated, they got together in groups and they got organized. The women got organized, everyone got organized, right down to the young people: they got organized. And so the homosexuals got organized too. And it wasn't with the intent to just have a bunch of homosexuals, but it was because they had more opportunities to be open about themselves. The rights that one has and the ability to exercise those rights are two distinct things.

The nation's revolutionary history, in the sexologist's account, constituted an era of radical change for both social and political structures in Nicaragua, from the emergence of homosexual rights to changing relationships. Linking the country's [End Page 177] communitarian past with contemporary articulations of rights, the speaker emphasizes both the possibilities for political organizing and the shape of those projects; it was a social space in which many people found themselves able to, or conversely confronted with, the "opportunity to be open about themselves." For both the students and the speakers, the ideals of choice, freedom from impediment, and the ability to exercise rights are explicitly related to both the revolutionary era and the contemporary moment. In both groups, prejudice and the censorship of sexuality were represented as a kind of premodern, or less developed, survival from Nicaragua's past. Discrimination, in other words, was ill suited to the aspirations of a more liberated present that is marked by a discourse of human rights. While discourses of rights and modernist progress appear in these narratives, they also explicitly invoke Nicaragua's national political history and revolutionary experience (Saldaña-Portillo 2003).

As students were filing out of the hall, I was curious about what they had learned from the presentations and the question and answer session. One young woman explained,

Well ... I learned that we need to have a campaign to protect the homosexuals. Because in one way or another, in some form, we have to protect them, because they are like kids. They can't take care of themselves, or that is, they need help.

Although she seemed well intentioned in her response, her condescending recognition was not what the panelists or the organizers were hoping to achieve. As with the journalists at the press conference, this particular student had learned that the marked categories, homosexuales and lesbianas, were the proper subject of sexual rights rather than, as SFFP proposes, the entirety of the Nicaraguan nation. Her comment was interesting in other ways too. In one sense, her response was not antihomosexual per se because she seemed to have digested the broader message of tolerance. Her expression of tolerance, however, demonstrates the ease with which rights may slip into a different register: one of patronizing support and a rhetoric of protecting the weak (Fassin 2011).

As the largest and most well-supported forum for sexual rights in Nicaragua, the Jornada has been an important site for activists to perform public and visible claims for sexual tolerance. Both because of its scale and its educational orientation, the Jornada has managed to generate an enduring epistemology for sexual rights advocacy. The values that appear in the campaigns' narratives - choice, individual decision-making, tolerance, development, progress, and the value 
of scientific knowledge - are explicitly mediated to present sexual rights in a particular way, drawing heavily upon liberalism, pluralist-multiculturalism, and an instantiation of a communalist past. This epistemic space aligns liberal discourses of subjectivity with the nation's Marxian history and more collective forms of political expression. Like the Sandinista era's national communitarian ethos, SFFP envisions [End Page 178] sexual rights for all, not just lesbianas and homosexuales specifically. It is a set of discourses and practices that marks the nation as a subject of, and for, sexual rights.

For some Nicaraguan sexual rights activists, however, the logics that have animated SFFP are opaque and therefore have not presented a sufficiently bold challenge to the antisodomy law. The failure of SFFP, from the point of view of Pride activists, lies in its breadth, which de-emphasizes and obscures the fact that it is Nicaraguan lesbianas and homosexuales who are the primary victims of sexual intolerance and marginalization.

\section{Pride and Praxis: Orgullo Lésbico-Gay}

It was around midnight at a disco gay in Managua that I first met proponents of Nicaraguan Orgullo Lésbico-Gay. As is often the case, there were few women at the disco that evening, but one young woman came to our table with an invitation in hand for the Orgullo festivities. When my friend and I arrived at the Pride event later that week at Galería Praxis, we were greeted by Humberto who was working as the door-diva for the event. Bedecked in gold lamé, a glittercovered fedora, and shoes to match, Humberto shuttled us to a table in the courtyard. As we waited for the night's activities to unfold, Bernice, one of the organizers, came to our table to welcome us. The banana trees that bordered the courtyard were festooned with multicolored Christmas lights — an ironic yuletide in June in the tropics.

The Orgullo Lésbico-Gay event, as with SFFP events, is intentionally scheduled in late June to coincide with global LGBT Pride events. The Pride party that Humberto and Bernice helped to organize featured a travesti lip-sync competition; similar performances have also been a staple of SFFP events. Poetry readings and a charla ("talk" or "discussion"), however, were unique to the Pride event. Steeped in the long tradition of Nicaraguan poetry, from Rubén Darío to the present, poetry added a particularly "Nica" slant to the occasion, as participants read their works to much applause and appreciation. Like the SFFP events, the Lesbian and Gay Pride event is coordinated by a handful of groups. But unlike SFFP, the Pride organizers have little institutional support. Their coordinators are not NGO staff members, but individuals and activists from smaller organization. Some of the groups that have worked to promote Pride events are comprised solely of Nicaraguans. Others, such as Grupo Arcoiris (Rainbow Group), are a transnational mix of foreign nationals and allies. Humberto explained that both women and men were involved in organizing the Pride events. In one of our many talks over the following years, Humberto went on to explain that placing lésbico first, in Lésbico-Gay, was an intentional decision to overcome the relative invisibility of lesbians in Nicaragua. Rather than the weeklong series of events hosted by SFFP, Orgullo Lésbico-Gay [End Page 179] was largely limited to one fiesta. The Pride event also attracted far fewer attendees than the SFFP closing parties that I attended. As Bernice lamented in an interview a couple of weeks following the Pride event, "the talks and discussions that we planned for Pride did not happen." She continued, somewhat discouraged, "it is easy to get people to come and party, but hard to get them to do political 
work." This, I said, is probably true just about everywhere. And perhaps, I offered, there is no shame in "party" politics?

As one of the primary organizers of Orgullo, Bernice was a firm believer in the political principles of Pride and we often discussed the meaning of Orgullo Lésbico-Gay in Nicaragua. Bernice was adamant that lesbian and gay pride was a "more visible" way to both publicly challenge Article 204 and make clear that Nicaraguan lesbian women and gay men were being denied their human rights. "Lesbian and Gay Pride," she explained, "really provokes the government, much more dramatically than a Sexuality Free from Prejudice." By naming a constituency under the mantles of "lesbian" and "gay," Orgullo presented an overt challenge to a legal regime that criminalized same-sex relationships. And thus, for Bernice lesbian and gay pride put Article 204 to the test. Furthermore, she explained, framing sexual rights in terms of lesbian and gay pride was important, "so the Nicaraguan people know that we are not going to stand for this homophobia." Maribel was quick to acknowledge that the Pride project needed to speak to the national level. However, rather than pursuing the SFFP ethos of investing the larger body politic with sexual rights, Bernice believed that political attention needed to focus upon the discrimination faced by lesbianas and gays as lesbianas and gays. The task for Nicaraguans was not to recognize their own investments in sexual rights but, rather, to overcome and confront their own homophobia.

The activists involved with the politics of Pride often utilized categories - lesbiana, gay, and Orgullo - that correspond to a global episteme of gay and lesbian rights discourses. However, proponents of Nicaraguan Orgullo did not consider these terms to be derivative discourses. Instead, they narrated their reckoning of "pride" in terms that went beyond sexuality. They often gestured to a national pride that echoed the antiimperialist sentiments for which Sandino was famous. Holding their events at the Galería Praxis, Orgullo activists created a symbolic association with the Marxist values of praxis. Activists involved with Orgullo also shared a keen awareness of the inequalities between the global north and the global south. They were always watchful for potential political imperialisms. Ivo, for example, had received funding from a U.S.-based NGO to develop a Pride-oriented pocket calendar. In describing how he chose the images and quotations for the agenda, he was very clear that he was able to develop the project without ideological input from the funding agency. His funding, he explained, "had no strings attached." Many of the Pride activists with whom I spoke, including Bernice and [End Page 180] Humberto were keenly attuned to the discourse regimes that they, as activists, were managing. Neither of them, for instance, considered the term "Pride" as derived, borrowed, or appropriated from LGBT Pride politics in the global north. As Bernice pointedly put it, "everyone has Pride. This is not just something that the gringos have."

\section{Potency and Palatability: Where Pride and Prejudice Diverge}

Sexuality Free from Prejudice was born in reaction to the antisodomy law, and since that time activists have been committed to alleviating the quotidian discrimination faced by those marked as sexually "other." But perhaps more importantly, SFFP embodies an epistemological perspective that locates sexuality within the national body and (bio)politic, not simply in the bodies of sexually marginalized populations. With this communitarian ethos, the discourses and practices of SFFP mirror the revolutionary principles of an earlier era that sought broad social transformation. Indeed, many of the activists responsible for crafting the public politics of SFFP 
were part of the revolutionary struggle and the social transformations that took place during the Sandinista decade, including a politics of sexuality that was more broadly based (Thayer 1997). The logic underlying SFFP is also similar to at least two other formulations of sexual rights. It reflects many of the tenets of lesbian and gay liberationist approaches that have sought to change the world rather than defining and defending a sexual minority. And it shares kinship with queer politics, which have envisioned an inclusive, postidentity imperative (Warner 1999). SFFP is also reminiscent of liberationist approaches that lobby for large-scale social change. However, it is dissimilar to classic formulations of gay liberation because it does not make the claim that "everyone is a little bit gay," or that there is a continuum of homoerotic desire that would emerge if it were not for oppressive prohibitions against it (Blasius and Phelan 1997). Rather, SFFP imagines a society "free from prejudice," indexing a tolerance for difference in a multiculturalist vein instead of drawing attention to the presence or absence of homoerotic desire. Because SFFP aims to include both sexually marginalized people and their straight allies, SFFP activists have developed a polymorphous subject for sexual rights that is similar to the umbrella approach favored by queer politics in the global north. However, unlike these iterations of postidentity, coalition sexual politics, SFFP does not stress radical difference from a heteronormative status quo. It is, rather, quite the opposite: a subtle, moderated, perhaps even careful and reformist approach to sexual rights that "normalizes" more than it queers (Warner 1999).

In employing the terms lesbiana and gay, Nicaraguan Pride activists have made semantic and symbolic links to a now globally recognized form of identity politics. By demarcating a constituency under the signs of lesbian and gay identity, Orgullo [End Page 181] reflects what has been termed a minoritizing approach — one that defines a minority (and marginalized) population as its subject for rights-based claims. Although Orgullo gestures to these sorts of global impulses, it is also an epistemological position firmly rooted in opposition to the (local) antisodomy law, and cognizant of potential political imperialisms. Orgullo, then, suggests a double quality of pride. First, it is to be venerated, shared, and deployed among, for, and on behalf of lesbian- and gay-identified people in Nicaragua and around the world. Second, it is a sentiment and a political ideology that resonates with and has the ability to capture some of the spirit of national patrimony. Orgullo Lésbico-Gay may utilize familiar frameworks of identity and lesbian and gay pride, but this approach is not, according to the activists involved, a replica of northern identity politics: it is not solely the provenance of "los gringos."

Demographically speaking, the activists involved in both campaigns are similar. Each set of advocates has members who consider themselves to be from the clases populares, and each has spokespersons from the middle and/or upper-middle classes. Each group has a mix of Nicaraguan nationals and foreign-born allies, many with experience in social justice activism spanning from Sandinismo to sexuality. The congruencies among the activists, however, extend beyond the composition of these constituencies and into the values that animate their interventions. Both Pride and Prejudice are hybrid ways of articulating translocal political values, placing them in conversation with local political logics. The distinct epistemological foundations of Pride and Prejudice help to illustrate the ways in which activists consciously engage in the production of political values and goals, articulating and mediating the ways that sexual rights ought to be understood by the Nicaraguan public. Each approach has differences in structure and scale, but where they diverge most is in the ways that activists imagine the subject of their interventions. Both Lesbian and Gay Pride and SFFP aspire to create a collective sensibility: an us around which to rally political sentiment. For Pride, "us" is comprised of lesbian women and gay men. For SFFP, "us" is envisioned as the Nicaraguan nation, in its entirety. Both Pride and 
Prejudice posed a challenge to the legal regime of Article 204; each approach articulated a critique of the legislation and, to different degrees, advocated for the sexual rights of same-sex attracted persons. For proponents of SFFP, Lesbian and Gay Pride may have overtly confronted the law, but its formula of minority rights failed to appeal to the larger population - an important audience for those who hope to change the country's moral climate. Activists committed to the politics of Pride, for their part, often found SFFP too conciliatory because it failed to draw attention to the specific ways in which gays and lesbians have faced legal and social marginalization. While Pride may be more potent and SFFP more palatable, their distinct epistemic logics illustrate how activists have engineered the subject of sexual rights. [End Page 182]

\section{Engineering the Epistemics of "Us"}

In classic formulations of vanguardism, intellectuals, artists, and other cultural experts take a preeminent role in constructing particular visions and agendas for their respective movements. As intellectuals and other artisanal discourse managers, such as activists, produce ideological infrastructures, they encounter opportunities as well as challenges. Activists assume a certain degree of authority when they claim an overt stake in transforming public understanding. But in occupying this position, activists must also take at least some responsibility for demarcating identities, whether national, ethnic, regional or, in this case, sexual. Indubitably, as activists seek to promote their own "version of social reality" (Verdery 1991:18), contentions and conflicts arise. Understanding how particular systems of meaning and action become produced, and specifically, how forms of knowledge are created and validated by certain experts, has been an enduring issue within anthropology (Boyer and Lomnitz 2005). Kay Warren (1998) found, for example, that in Guatemala's pan-Mayanist movement Mayan intellectuals played an instrumental, if sometimes fraught, role in creating the movement's agenda. Mayan activists were explicit about the need to craft an intellectual armature that emphasized language preservation and placed ideological attention on indigenousness. Like Mayan activists, Nicaraguan sexual rights advocates have been engaged in a deeply reflexive process among themselves. They have maintained an acute awareness about which specific political tropes are being operationalized, from Sandinismo and human rights to Pride and Prejudice.

The deliberations around how to best present the politics of sexual rights in the public domain reflect many of the contingencies of Nicaragua's contemporary era. As Rafael De la Dehesa (2010) has documented in his comparison of LGBT political movements in Mexico and Brazil, sexual rights activists working in the global south have had to contend with neoliberal economic contexts and changing relationships between the state and civil society. Sexual rights activists in Nicaragua have continued their struggle as a mediation between state and civil society politics and possibilities. Many of the NGOs that were instrumental to organizing in the early 1990s continue to promote sexual diversity and equality through a steady stream of social justice campaigns. However, new generations of sexual rights activists have also founded their own organizations and coalitions. New constellations of activists and priorities have meant an expansion of the terminological universe that sexual rights advocates employ - the terms transgender and intersex, for instance, are more prevalent than they were in the past. The fact that "sexual diversity" parades in Managua have blossomed in the last several years suggests that while the politics of pride may be embedded in activists' sentiments on the street, the discourse 
of diversity and "free from prejudice" appears to have prevailed. At the level of the state, changes are afoot as well. In 2009, the Nicaraguan [End Page 183] government under Daniel Ortega ${ }^{6}$ implemented an Ombudsperson's Office for the Defense of Sexual Diversity Rights. It was a move that garnered ire from religious institutions in the country, but it also signaled a commitment to providing a legally codified, structural dimension to sexual rights.

As with many contemporary political projects, Nicaraguan activists must mediate among ideological paradigms, financial contingencies, and local political histories and priorities (Hale 2006; Speed 2007). The approaches that advocates have implemented rely on the power of civil and human rights to transform not only law but also cultures (Paley 2001). In turn, these political processes highlight the importance of understanding activists' strategies as expert and artisanal interventions in public knowledge, not simply instrumental acts to achieve policy outcomes. Through a process of framing their goals for collective action, activists become "signifying agents" (Benford and Snow 2000:613) who produce and maintain particular forms of meaning for their constituents, but also, importantly, for other observers, opponents, or onlookers. Sexual rights activists, then, are both managers of political logics and strategists of struggle. Tacking between explicit declarations and inferred identities, activists craft an epistemological framework for sexual rights that is situated in multiple registers, including universal liberation and minority rights, as well as the communitarian ethos of the revolutionary era.

\section{Notes}

${ }^{1}$ Elizabeth Povinelli defines autological discourse as "discourses, practices, and fantasies of self-making, self-sovereignty, and the value of individual freedom," which she juxtaposes against "genealogical" forms that comprise the "discourses, practices, and fantasies of inheritances of various sorts as constraints on the self-actualizing subject" (2007:570).

${ }^{2}$ See Howe (2013).

${ }^{3}$ Often used to account for same-sex sexual practices between men in Latin America and the Middle East (among other places), the "Mediterranean model" draws on concepts of honor/shame, activity/passivity, and masculine/feminine gender and sexual roles. This model has been critiqued because, as with many models, it cannot fully account for the actual diversity of sexual practices and perceptions of those practices in different settings. Further, given that what goes on "behind closed doors" often remains elusive to the social scientific gaze, it is difficult to know how accurate the model is, or ever was. See Carrier (1995), Kulick (1998), Lancaster (1992), Murray (1995), Parker (1998), Priuer (1998).

${ }^{4}$ Discussions of the problematic implementation of universal (sexual) categories can be found in the following (among others): Carrillo (2001), Kulick (1998), Manalansan and CruzMalave (2002), Parker (1999).

${ }^{5}$ While the use of the term "closet" (in English) might be an instance of the global diffusion of LGBT discourse, most Nicaraguans use the English term "closet" rather than the Spanish term armario to describe all closets, not only the LGBT variety.

${ }^{6}$ As president once again, Ortega has allied himself with the neosocialist, anti-imperialist values of Hugo Chávez's Bolivarian Revolution. However, Ortega has also embraced social conservatism. In the run-up to the 2006 elections, Ortega supported a vote in the Nicaraguan 
National Assembly to criminalize abortion in all forms including therapeutic abortion to save a woman's life (see Howe 2013).

\section{References Cited}

Adam, Barry D. (1993) In Nicaragua: Homosexuality without a Gay World. Journal of Homosexuality 24:171-181.

Babb, Florence E. (2001) After Revolution: Mapping Gender and Cultural Politics in Neoliberal Nicaragua. Austin: University of Texas Press.

— (2003) Out in Nicaragua: Local and Transnational Desires After the Revolution. Cultural Anthropology 18(3):304-332.

Benford, Robert D., and David A. Snow. (2000) Framing Processes and Social Movements: An Overview and Assessment. Annual Review of Sociology 26:611-639.

Blasius, Mark, and Shane Phelan. (1997) We Are Everywhere: A Historical Sourcebook of Gay and Lesbian Politics. London: Routledge.

Boellstorff, Tom. (2003) Dubbing Culture: Indonesian Gay and Lesbi Subjectivities and Ethnography in an Already Globalized World. American Ethnologist 30(2):225-242.

Bolt Gonz'alez,Mary. (1996) Nicaragua. In Unspoken Rules: Sexual Orientation and Women's Human Rights. Rachel Rosenbloom, ed. Pp. 121-137. London: Cassell.

Boyer, Dominic, and Claudio Lomnitz. (2005) Intellectuals and Nationalism: Anthropological Engagements. Annual Review of Anthropology 34:105-120.

Butler, Judith. (2004) Undoing Gender. New York: Routledge.

Carrier, Joseph. (1995) De Los Otros. New York: Columbia University Press.

Carrillo, Héctor. (2001) The Night Is Young: Sexuality in Mexico in the Time of AIDS. Chicago: University of Chicago Press.

De la Dehesa, Rafael. (2010) Queering the Public Sphere in Mexico and Brazil: Sexual Rights Movements in Emerging Democracies. Durham, NC: Duke University Press.

Dye, David R., and David Close. (2004) Partrimonialism and Economic Policy in the Alemán Administration. In Undoing Democracy: The Politics of Electoral Cuadillismo. David Close and Kalowatie Deonandan, eds. Pp. 119-142. Lanham: Lexington Books.

Fassin, Didier. (2011) Humanitarian Reason: AMoral History of the Present. Berkeley: University of California Press.

Ferguson, Ann. (1991) Lesbianism, feminism and empowerment in Nicaragua. Social Review 21(3): 75-97.

Field, Les W. (1999) The Grimace of Macho Ratón: Artisans, Identity and Nation in LateTwentieth-Century Western Nicaragua. Durham, NC: Duke University Press.

González-Rivera, Victoria. (2011) Before the Revolution: Women's Rights and Right-Wing Politics in Nicaragua, 1821-1979. University Park, PA: Pennsylvania State University Press.

Goodale, Mark, and Sally Engle Merry, eds. (2007) The Practice of Human Rights: Tracking Law between the Global and the Local. Cambridge: Cambridge University Press.

Hale, Charles. (2002) Does Multiculturalism Menace? Governance, Cultural Rights and the Politics of Identity in Guatemala. Journal of Latin American Studies 34:485-524. 
(2006) Más Que Un Indio (More Than an Indian): Racial Ambivalence and the Paradox of Neoliberal Multiculturalism in Guatemala. Santa Fe: School of American Research Press. Howe, Cymene. (2008) Spectacles of Sexuality: Televisionary Activism in Nicaragua. Cultural Anthropology 23(1): 48-84.

(2013) Intimate Activism: The Struggle for Sexual Rights in Postrevolutionary Nicaragua. Durham, NC: Duke University Press.

Kampwirth, Karen. (2006) Resisting the Feminist Threat: Antifeminist Politics in PostSandinista Nicaragua. NWSA Journal 18(2):73-101.

Kulick, Don. (1998) Travesti: Sex, Gender, and Culture among Brazilian Transgendered Prostitutes. Chicago: University of Chicago Press.

Lancaster,Roger. (1992) Life is Hard: Machismo, Danger, and the Intimacy of Power in Nicaragua. Berkeley: University of California Press.

Manalansan, Martin, and Arnaldo Cruz-Malave. (2002) Queer Globalizations: Citizenship and the Afterlife of Colonialism. New York: New York University Press.

Mitchell, Timothy. (2002) The Rule of Experts: Egypt, Techno-Politics, Modernity. Berkeley: University of California Press.

Molyneux, Maxine. (1985) Mobilization without emancipation? Women's interests, the state, and revolution in Nicaragua. Feminist Studies 11(2):227-254.

Paley, Julia. (2001) Marketing Democracy: Power and Social Movements in Post-dictatorship Chile. Berkeley: University of California Press.

Parker, Richard. (1999) Beneath the Equator: Cultures of Desire, Male Homosexuality, and Emerging Gay Communities in Brazil. New York: Routledge.

Postero, Nancy. (2006) Now We Are Citizens: Indigenous Politics in Post-multicultural Bolivia. Stanford: Stanford University Press.

Povinelli, Elizabeth A. (2007) Disturbing Sexuality. South Atlantic Quarterly 106(3):565-576.

Priuer, Annick. (1998) Mema's House, Mexico City: On Transvestites, Queens and Machos. Chicago: University of Chicago Press.

Randall, Margaret. (1993) To Change Our Own Reality and the World: A Conversation with Lesbians in Nicaragua. Signs 18(4):907-924.

—(1994) Sandino's Daughter's Revisited: Feminism in Nicaragua. New Brunswick, NJ: Rutgers University Press.

Saldaña-Portillo, María Josefina. (2003) The Revolutionary Imagination in the Age of Development. Durham, NC: Duke University Press.

Speed, Shannon. (2007) Rights in Rebellion: Indigenous Struggle and Human Rights in Chiapas. Stanford: Stanford University Press.

Thayer,Millie. (1997) Identity, Revolution and Democracy: Lesbian Movements in Central America. Social Problems 44(3):386-406.

Verdery, Katherine. (1991) National Ideology Under Socialism. Berkeley: University of California Press.

Warner, Michael. (1999) The Trouble with Normal: Sex, Politics, and the Ethics of Queer Life. New York: Free Press.

Warren, Kay B. (1998) Indigenous Movements and Their Critics: Pan-Maya Activism in Guatemala. Princeton, NJ: Princeton University Press.

Žižek, Slavoj. (2005) Against Human Rights. New Left Review 34(July-August):115-134. 